\title{
Su Kamusallığının Değișen Niteliğinin Değerlendirilmesinde Suyun Finansmanının İncelenmesi: Trabzon Büyükşehir Belediyesi Örneği ${ }^{1}$
}

\section{$* * *$ \\ Analysis of Water Funding in Assesment of the Changing Attribute of Water Publicity: A Case of Trabzon Metropolitan Municipality}

\author{
Sonay Akar \\ Giresun Üniversitesi, Sosyal Bilimler Enstitüsü, Ph.D. Student \\ tsonay61@gmail.com, (ORCID:0000-0002-7707-3465)
}

\section{Özet}

Doğal bir kaynak, bir insan hakkı ve canlı yaşamı için hayati önemde bir faktör (kaynak) olan su niteliği gereği kamusaldır. Son 30 yıllık süreçte suyun niteliğinde bir değişim yaşanmakta ve su özel bir mala dönüşmektedir. Bu çalışmada niteliği gereği kamusal olan suyun özel bir mala dönüştüğünü küresel düzeyde ispatlamaktır. Bunu yapabilmek için suyun faydasını ve suyun finansmanında kullanılan fiyatlandırma ve politikaları incelemek gerekmektedir. Türkiye'de ve diğer ülkelerde suyu özelleştirme çabalarının altında, sudaki kar potansiyelinin olduğu tespit edilmiştir. Çalışmada, kamusal alan araştırması örneğinde, suyun finansmanı bu alandaki faaliyet raporları verileri ile birlikte matematiksel hesaplama yöntemi ile analiz edilmiştir. $\mathrm{Bu}$ çerçevede çalışmanın hipotezi; su kıtllğının neden olduğu ve canlı yaşamını (insan yaşamını) tehdit eden olumsuzluklardan dolayı suyun kamusal kalmasının gerekliliği ortaya koyulmuştur.

Anahtar Kelimeler: Su, Küreselleşme, Kamusallık, Özelleştirme, Finans.

JEL Sinıflandırması: C69, F65, H41, Q25

\begin{abstract}
Water is public by its nature which is a natural resource, a human right and a vital factor (resource) for living life. In the last 30 years, there has been a change in the quality of water and water has become a special good. İ this study, it is to prove at
\end{abstract}

\footnotetext{
${ }^{1}$ Bu makale 2019 yılı Nisan ayında gerçekleştirilen "Artvin International Social Congress of Social Sciences" adlı kongrede sözlü bildiri olarak sunulmuştur.
} 
the global level, has turned into a special good that water which is public by nature. To do this, it is necessary to examine the benefits of water and the pricing and policies used to finance water. Turkey and in other countries under the water privatization efforts, it was found that the profit potential of water. In the study, in the case of public domain research, water financing was analyzed with mathematical calculation method together with the activity reports data in this field. In this context, the hypothesis of the study; has been demonsrated the necessity of water to remain public due to the shortcomings caused by water scarcity and threatening the living life (human life).

Keywords: Water, Globalization, Publicity, Privatization, Finance.

JEL Classification: C69, F65, H41, Q25

\section{GíRIŞ}

$\mathrm{Su}$, canlı yaşamının temel kaynağı ve ikamesi mümkün olmayan nitelikte bir varlıktır. Aslında dünyada bulunan toplam su miktarının \%2,5'luk kısmı tatlı sudur. $\mathrm{Bu}$ miktar yeryüzünde eşit ve dengeli olarak dağılmamaktadır. Genel olarak bakıldığında ise, dünyanın \%75'i sularla kaplıdır. Bu suyun \%70'lik miktarı Grönland'da ve Antartika'da yer alan buzulların altında bulunmaktadır. Geriye kalan \%5'lik dilimin önemli bir bölümünü de yer altı suları oluşturmaktadır. Bu durum dünyada paylaşılması gereken tatlı su miktarının \%2,5 ve 3 düzeyinde sınırlı ve kit bir kaynak olması sonucunu doğurmaktadır (Yıldız, 2004, s.9).

Suyun doğal kaynak olarak arzının az olması dışında, küreselleşme sürecinde dünyada yaşanan birtakım değişiklikler suyun paylaşılmasında bazı sorunları da beraberinde getirmektedir. Ülkelerdeki nüfus artışı, tarım, sanayi, enerji gibi sektörlerde suyun kullanımının yaygınlaşması, ülkelerin gelişmişlik düzeyinin artışına bağlı olarak suya gereksinimin artması suyun paylaşılmasında ortaya çıkan sorunların temel kaynağını oluşturmaktadır.

$\mathrm{Su}$, tarihi süreç içinde canlılar için bir hak, doğal bir kaynak ve tüketiminden kimsenin mahrum birakılamadığı kamusal bir mal ve hizmet olarak değerlendirilmiştir. Dünya'da son 30 yılda, Türkiye'de ise son 20 y1lda su konusunda bu sürecin tersine işlediği görülmektedir. Su üzerinde hâkim görüş, neo liberal politikalar aracılığıyla suyun piyasalaştırılmasıdır. Gerekçe olarak ta, kamusalcı yaklaşımın suyu kıt bir kaynak haline getirdiği ileri 
sürülmektedir. Su kaynaklarına sahip olan ülkelerin gelişmişlik seviyeleri farklı olmakla birlikte, su kaynaklarını daha çok gelişmiş ülkeler kontrol etmek istemektedirler. Buna karşın, gelişmiş ülkelerin suya erişimde ve kullanımında üstünlükleri vardır. Bu sayede sanayileşmiş ülkelerin suyun kullanımında artan üstünlükleri, bu ülkeleri yeni su piyasası elde etme arayışlarına sürüklemektedir.

Su yaklaşı 1 trilyon dolarlık kara sahip küçümsenmeyecek derecede önemli bir piyasadır (Karakılçık, 2011, s.78). Dolayısıyla küresel anlamda su üzerinde ekonomik güç ve siyasi politikalar oluşturma çabaları suyun bu özelliğinden gelmektedir.

Yeryüzünde su kaynaklarının yönetimi, küreselleşme ile birlikte artık uluslararası ortama taşınmıştır. Milli sınırlar içindeki sularda dahi uluslararası öncelikler mevcuttur. Bu çerçevede; dünya su yönetimi küresel aktörlerin belirlediği politikalar tarafından yürütülmeye başlamıştır.

Dünyada ve Türkiye'de su yönetimi, kamu mülkiyetine dayanan, suyu insan hakk1 olarak gören arz odaklı yapısından; özel mülkiyete konu ekonomik bir mal olarak görüp fiyatlandırılabilen talep odaklı bir yapı haline dönüşmüştür. Küresel aktörler stratejilerini, 1800'lü yıllarda geri kalmış ülkelerin yer altı kaynaklarını, 1900'lü yıllarda petrol ve enerji kaynaklarını, 2000'li yıllarda ise su kaynaklarını elde etmek üzere belirlemektedirler (Karakılçık, 2011, s.75). Küreselleşen ve dönüşüm yaşanan dünyada su talebinin artmasına bağlı olarak yeni mülkiyet haklarının oluşması sonucu, suyun kamusal niteliği küresel sebeplerle değişime uğramaktadır.

$\mathrm{Bu}$ çalışmada, temel bir yaşam kaynağı, bir insan hakkı nitelendirmesiyle kamusal bir mal olan suyun 21.yüzy1lda kit bir kaynak olduğu ve kamunun israfa yol açtığı gerekçeleriyle yapılan özelleştirmeler sonucu suyun ticari bir mala dönüştürüldüğü küresel düzeyde ortaya koyulmuştur. Bu çalışmanın temel amacı, nitelik olarak kamusal bir mal ve hizmet olarak kalması gereken suyun, gerçekte nasıl bir yapısal dönüşüm içerisinde olduğunu belirlemektir. Bunu yapabilmek için suyun faydasını ve suyun finansmanında kullanılan fiyatlandırma ve politikaları incelemek gerekmektedir. 
Türkiye'de ve diğer ülkelerde suyu özelleştirme çabalarının altında, sudaki kar potansiyelinin olduğu tespit edilmiştir (TMMOB, 2009, s.12). Özellikle su kıtlığı ve su sorunu yaşayan az gelişmiş ülkelerdeki bu özelleştirme çabaları sonucu canlı yaşamını tehdit eden olumsuzlukların yaşanmasına neden olmaktadır.

$\mathrm{Bu}$ çerçevede çalışmanın hipotezi; su kıtlığının neden olduğu ve canlı yaşamını (insan yaşamını) tehdit eden olumsuzluklardan dolayı suyun kamusal kalmasının gerekliliğini ortaya koymaktır.

\section{LITERATÜR}

Kamu ve özel sektör su hizmetlerinde işletmelerin performansının karşılaştırılmasında birçok çalışma yapılmıştır. Su hizmetlerinin kamu tarafından sunulmasından kaynaklı verimsizliği kanıtlanamamıştır. 2005 yılında, DB raporunda su sektörünün verimliliğine dair ekonometrik veriler incelenmiştir. Gelişmiş ve gelişmekte olan ülkelerin verileri incelediğinde, kamu ve özel sektör hizmet sunucuları arasında pek fark bulunamamıştır (Hall ve Lobina, 2005).

Shirley ve Walsh (2000), özel sektör su hizmetlerinin verimliliğinin incelendiği bir başka çalışmada, 24 karşılaştırmalı çalışmanın yarısında özel sektörün daha verimli, yedi tanesinde bir fark olmadı̆̆ı, beş tanesinde ise kamu sektörünün daha verimli olduğunu saptamışlardır. Fakat bu çalışmalarda sadece iki tanesi su sektörünü incelemektedir. Dolayısıyla su sektöründe özel sektörün daha verimli olduğunu kabul etmek doğru bir değerlendirme olmayacaktır. ABD'de özel sektör verimliliğini kabul eden çalışma sadece iki örneğe dayandırılmışken, kamu sektörünün verimliliğini kabul eden çalışma ise 214 örneğe dayandırılmıştır. Kamu ve özel sektör arasında su hizmetleri verimliliği konusunda yapılan 52 çalışmanın 32'sinde kamunun özel sektörden daha verimli olduğu, 15 çalışmada kamu ve özel sektör arası pek bir fark olmadığı, 5 'inde ise su hizmetlerinin kamunun mülkiyetinde daha verimli olduğu sonucuna ulaşılmıştır (Shirley ve Walsh, 2000, s.51).

Brookings Enstitüsü (2004), tarafından yayınlanan önemli bir diğer çalışmada Arjantin, Bolivya ve Brezilya'da su ve kanalizasyon bağlantılarını 
incelenmiştir. Bu çalışma kamu sektörü ve özel sektörün etkin olduğu şehirleri incelemiştir. Bu çalışmanın sonucunda özelleştirmelerle bağlantı miktarında artışlar görünmüş; fakat bu artışın su hizmetlerini kamuda koruyan şehirlerle eşit durumda olduğu gözlemlenmiştir. Fakat buna karşın fiyatların da arttığ ve sızıntı, kaçak su kullanımı problemleri ile mücadele konusunda kamu işletmelerinden daha kötü oldukları görülmüştür (Hall ve Lobina, 2005, 4).

Kirkpatric vd. (2004), Afrika'daki su özelleştirmeleri hizmetin kalitesizliği ve yoksullara su bağlantısı yapılamaması gibi olumsuz sonuçlar ortaya çıktığı görülmüştür. Ayrıca, 110 su işletmesinin 14'u özel olmasına karşın maliyetler açısından pek bir fark bulunamamıştır.

Estache ve Kouassi (2002), yapılan bu çalışmada özel firmaların daha verimli olduğu sonucuna varılmış olsa da suyun üretim, dağıtım ve su verimliliğini sağlamada özel sektörün etkin olmadığı gözlemlenmiştir. Burada dikkat çekilmesi gereken iki nokta vardır. Birincisi; bu çalışmada sadece iki özel firma vard1, ikincisi; bulunan verimlilik farkı kurumun kalitesinden kaynaklanan bir fark olduğu görülmüştür (Estache ve Kouassi, 2002).

Asya Kalkınma Bankası (2004), bu çalışmada 18 şehri incelemiştir. Asya'da iki şehir olan Manila ve Cakarta'da su hizmetleri taşeronlar aracıllğıyla verilmektedir. $\mathrm{Bu}$ taşeronların su hizmetinin verdirilmesinde yatırım, sızıntı ve daha birçok konuda kamudan daha başarısız oldukları gözlemlenmiştir (Hall ve Lobina, 2005). Fiyat seviyesi, bağlantı bedeli, 24 saat boyunca su sağlanması, suyun tüketiciye maliyeti, birim maliyet, gelirlerin giderleri karşılama oranı düzeyinde altı değişkende ortalama bir performans söz konusudur. Özel sektör firmalarının olduğu şehirler para toplama verimliliği ve bağlantı başına çalışanların sayısını azaltmasında iyi performans göstermiştir (Topçu, 2002, s.26).

Çevre Mühendisleri Raporu (2008), yapılan çalışmalar ve araştırmalar sonucunda, gelişmişlik düzeyi farklı birçok ülkede kamu ve özel sektör su işletmelerinin performansları karşılaştırıldığında, suyun kamuda olmasından kaynaklı verimsizliği belirlenememiştir. Su hizmetlerinin özelleştirilmesine dayanak olarak sunulan kamunun verimsizliği ve özel sektörün verimliliği iddiası da etkinliğini kaybetmiştir ("Çevre Mühendisleri Raporu”, 2008, s.3). 


\section{SUYUN KAMUSAL NITTELİĞİIIN ARGÜMANLARI}

\subsection{Doğal Kaynak Olarak Su}

$\mathrm{Su}$ insan yaşamı için vazgeçilmez ve ikame edilemeyen bir kaynak olduğu kadar ekonomide tarım, sanayi ve daha birçok alanda temel unsurdur (USİAD, 2007, s.15):

Su kaynağı, tarım ve sanayi için önemli bir üretim faktörüdür. Dünya'daki toplam su tüketiminin yaklaşık \%73'ü tarımda kullanılmaktadır. 1995 yılı itibariyle dünyada sulanan tarım alanları 253 milyon hektar iken, 2010 y1linda 290 milyon hektara, 2023 y1linda ise 330 milyon hektara ulaşılması beklenmektedir (USİAD, 2007, s.15).

Türkiye'de Gap tarafindan 2000 y1lında Halcrow-Dolsar-Rwc ortak girişimine yaptırılan çalışmada tarımsal sulamada su ücretlerinin giderleri karşılamada yetersiz olduğu tespit edilmiştir. Bu durumda su fiyatlandırması piyasa talep şartlarına göre gerçekleştirildiğinde fiyatlar artacak ve birçok tarım üreticisi suya erişemeyecek ve suya erişmede kaçak yollara başvurması sonucunu doğuracaktır (Aydoğdu, Mancı ve Aydoğdu, 2015).

Doğal bir kaynak olan su sayesinde sanayi mal üretilmektedir. Sanayi malı üretilirken çevre kirliliğine de neden olmaktadır. Bu durum son y1llarda çevreye daha az zarar veren sanayi ürünlerinin tercih edilmesine neden olmaktadır. Çevre ile birebir uyumlu üretim yapılması doğal kaynak olan suyun daha etkin ve verimli kullanılmasına olanak vermektedir.

Su bir enerji kaynağıdır. Gelişen ekonomi ve sanayileşmeye bağlı olarak enerjiye olan talebi de beraberinde getirmektedir. Türkiye'de 1950'li yıllarda sadece $800 \mathrm{GWh}$ enerji üretimi yapilırken, bugün bu miktar 150000 GWh'e ulaşmıştır. Enerji üretimimizin \%31'i yenilenebilir hidrolik kaynaklardan sağlanmaktadır. 2030 yılına kadar elektrik enerjisi talebindeki artışın \%8 civarında gerçekleşeceği öngörülmektedir (DSİ, 2011, s.34).

Suyun alternatifsizliğinin dayandığ 1 temel nokta, suyun ticari bir mal değil; bir doğal kaynak olmasıdır. Suyu kullanma, sudan kar elde etme ve suyu kirletme hiçbir sınıfa ait değildir. 20-30 yıl kadar önce su kamu malı olarak değerlendirilmekte olduğu görülmüştür. Devlet ve yerel yönetimler su 
kaynağının yönetimi, temini gibi konularda tek belirleyici kurum olarak kabul edilmiştir. Ama 1980'li yıllardan itibaren liberalizm etkili olmaya başlayınca, sermayedar gruplar suyun da özelleştirilmesi gerektiğini savunmaktadırlar.

\section{2. İnsan Hakkı Olarak Su}

Suyun insan hakkı olarak nitelendirilmesinin temelinde canlı yaşamının sağlık kaynağı olması yatmaktadır. Yeryüzünde yaşayan canlıların vücutlarının \%50 ila 80’ni sudan oluşmaktadır (Kılıç, 2008, s.163). Dolayısıyla su hakkının ihlal edilmesi, aynı zamanda sağlık hakkının da ihlali anlamına geldiği ifade edilebilmektedir.

Su hakk1, uluslararası toplantı ve kongrelerde dile getirilmiştir. Ancak bir hakkın uluslararası alanda geçerli ve bağlayıcı olması için antlaşmalarda yer alması gerekmektedir. Bu yüzden su hakkı BM İnsan Hakları Evrensel Beyanname'sinde sözleşmelerle dolaylı olarak belirtilmektedir. Su hakkına uluslararası platformda birçok belgede yer verilmiştir (Öztunalı, 2002, s.43):

$\checkmark 1949$ Cenevre Antlaşması Ek Protokol-I, 1977, (54. Md. ve Ek Protokol-II, 14.md.);

$\checkmark$ Stockholm Deklarasyonu - 1972, (1. ve 2. Prensibleri);

$\checkmark$ CEDAW - Kadınlara Karşı Her Türlü Ayrımcılığın Önlenmesi Uluslararası Sözleşmesi, (1979, 14. md.);

$\checkmark$ CRC - Uluslararası Çocuk Hakları Sözleşmesi - 1989, (24. Md.);

$\checkmark$ Dublin Deklarasyonu - 1992, (4. İlke);

$\checkmark$ Amsterdam Deklarasyonu - 1992, (1. Ve 2. Maddeler);

$\checkmark$ BM. Azınlıkların Her Türlü Ayrımcılığına Karşı Korunması konusunda, Kişisel ve Çevre Hakları İlkeleri Deklarasyonu Projesi 1994.

\section{SUYUN TICARILEŞMESININ EKOPOLITİĞİ: SUYUN DEĞISSEN YAPISI}

Suyun piyasalaşması süreci 1980'li yıllardan itibaren başlamıştır. Bu tarihten önce suda temel aktör kamu ve kamunun uyguladığı politikalar olmuştur. Küreselleşme ile birlikte değişen paradigma anlayışı ulusallık kavramının yerine, uluslararası öncelikleri ön plana çıkarmışıı. Bu bağlamda su kaynakları, yönetimi ve hizmetinin verdirilmesinde ulusal sular olsa dahi, 
uluslararası öncelikler etkin olmaya başlamıştır. Su yönetiminde önemli role sahip olan uluslararası kuruluşlar suyun ticarileştirilmesinde konferanslar, su forumları ve deklarasyonlar yapmışlardır. Değiştirilen nitelikle beraber uygulanan su politikaları da değişmektedir. Dünya su yönetimi, bu kuruluşların belirlediği politikalar çerçevesinde yürütülmektedir.

Tablo 1. Su Politikalarının Değişen Yapısı

\section{Antlaşmalar ve Yıl Su Politikaları}

Stockholm
Deklarasyonu (1972)

Dublin Beyanı (1992) Suyun ekonomik değeri vardır, ekonomik mal olarak ele alınmalidır.

Rio Deklarasyonu ve Su doğal bir kaynak, aynı zamanda sosyo-ekonomik bir mal Gündem 21 (1992) olarak algılanmalıdır.

Dünya Bankası Suyun özelleştirilmesi ve kamunun su yönetiminden Yaklaşımı uzaklaştırılması gerekmektedir.

Birinci Dünya Su Su kaynaklarının sürdürülebilirliği sağlanmalı ve suyun Forumu(1997) temel bir insan ihtiyacı olduğu vurgulanmalıdır.

\begin{tabular}{ll}
\hline $\begin{array}{l}\text { İkinci Dünya Su } \\
\text { Forumu (2000) }\end{array}$ & Su özelleştirmeleri hızlandırılmalıdır. \\
\hline $\begin{array}{l}\text { Üçüncü Dünya Su } \\
\text { Forumu(2003) }\end{array}$ & $\begin{array}{l}\text { Suyun bir insan hakkı olduğuna dair değerlendirme } \\
\text { bulunmamaktadır. }\end{array}$ \\
\hline $\begin{array}{l}\text { Dördüncü Dünya Su } \\
\text { Forumu (2006) }\end{array}$ & Su hakkından bahsedilmemektedir. \\
\hline
\end{tabular}

Beşinci Dünya Su

Forumu, (2009)

Su hakkı kavramı görmezden gelinmiştir. 
Altıncı Dünya Su Suyun etkileşim içinde olduğu tüm sektörlerle bağlantısı

Forumu, (2012) tartışılmıştır.

Yedinci Dünya Su

Suyun geleceğinden çok gelecekteki suyun durumu

Forumu, (2015)

gelecekteki değişimlerle ele alındı. Politik gündemdeki

önemini artırmak adına yol haritası belirlendi.

İklim, insanlar, ekosistemler, finans, mültecilerin durumu

Sekizinci Dünya $\mathrm{Su} \quad$ konuları görüşüldü. KKTC su temini projesi önemli

Forumu, (2018) görüldü.

Kaynak: (Kartal'dan aktaran Mert, 2008)

1997 y1lında başlayıp dört yılda bir düzenlenen dünya su forumlarında, suyun ekonomik bir mal olduğu ve özelleştirilmesi en önemli argümandır. Su forumları, su piyasasında uluslararası su şirketlerinin hâkimiyetini güçlendirici eğilimler ortaya çıkarmakta ve küresel rekabet koşullarını hazırlamaktadır. Su piyasasındaki nispeten küçük aktörler büyük aktörlerin tüm dünyada hareket etmeleri nedeniyle ortaklık sürecine zorlamaktadır. $\mathrm{Bu}$ durum su piyasasında tekelleşme eğilimlerinin ortaya çıkmasını zorunlu hale getirmektedir.

\title{
2.1. Suyun Kamusal Alandan Ekonomik Mala Dönüşümünün Gerekçeleri
}

\author{
$\checkmark$ Arzı kit ve alternatifsiz \\ $\checkmark$ Talebi sürekli ve sonsuz \\ $\checkmark$ Nüfus artışı \\ $\checkmark$ Ekonomik ve sosyal açıdan kulanım değeri yüksek
}

Su hizmetlerinin özelleştirilmesinin bir sonucu olarak, su kaynaklarının yönetimine sahip olan özel firmalar kiralama ve dağıtımda aşırı derecede rekabetle birlikte firmalar el değiştirmekte ve bu yüzden tekelleşmeye sebebiyet vermektedir.

Suyun özelleştirilmesinin en önemli gerekçelerinden biri olarak sunulan su kıtlığını fiziksel ve ekonomik olarak tanımlamak gerekir. Fiziksel 
su k1tlı̆̆1, su kaynaklarına sahip olunamayan durumdur. Ekonomik su kitlığ1 ise, su kaynaklarına erişimde mali imkanların yetersizliğidir.

Uluslararası ortamlarda yaygin şekilde savunulan ve bir paradigma haline gelen su kıtlığı düşüncesinin küresel su şirketlerinin suyu bir yatırım olarak görmelerinden önce mi, yoksa sonra $\mathrm{m}$ 1 ortaya çıktığı tartışılması gereken önemli bir konudur.

Dünya'da yaşanan su kıtlığının nedenleri olarak yenilenebilir kaynak miktarının sınırlı oluşu, suyun kullanımından doğan hatalar, zaman geçtikçe artan yüksek nüfus sebebiyle kişi başına düşen su kaynaklarını azaltması şeklinde özetlenebilir. İklim değişiklikleri hariç tutulmak üzere dünyada yenilenebilir su kaynakları miktarı sabittir. Yenilenebilir su kaynaklarından daha fazla suyun tüketilmesi durumunda, temiz ve kullanılabilir su kaynakları da gittikçe azalmaktadır.

Su kaynağı bakımından yılda kişi başına düşen kullanılabilir su miktarı $1000 \mathrm{~m}^{3}$ 'den az ülkeler su fakiri, $8000-10000 \mathrm{~m}^{3}$ arası ülkeler ise su zengini olarak sayılmaktadır (DPT, 2007, s.6).

Tablo 2. 1995 ve 2025’te Dünya'da Kişi Başına Kullanılabilir Su Potansiyeli

\begin{tabular}{lccccc}
\hline \multirow{2}{*}{ DURUM } & \multirow{2}{\text{Su}}{$\begin{array}{c}\text { Kaynă̆ı } \\
\mathbf{m}^{\text {3/Kişi }}\end{array}$} & $\begin{array}{c}\text { Nüfus } \\
\text { (Milyon) }\end{array}$ & $\begin{array}{c}\text { Dünya } \\
\text { Nüfusuna } \\
\text { Oranı } \\
(\%)\end{array}$ & $\begin{array}{c}\text { Nüfus } \\
\text { (Milyon) }\end{array}$ & $\begin{array}{c}\text { Dünya } \\
\text { Nüfusuna } \\
\text { Oranı } \\
(\%)\end{array}$ \\
\hline Su Kıtlığı Var & $<500$ & 1007 & 19 & 1783 & 25 \\
\hline Su Yeterli & $500-1000$ & 587 & 10 & 624 & 9 \\
\hline Sınıflandırma & $>1700$ & 3091 & 55 & 3494 & 48 \\
Dışı & & 241 & 4 & 296 & 4 \\
\hline Toplam & & 5665 & 100 & 7274 & 100 \\
\hline
\end{tabular}

Kaynak: DPT, (2007:108) 
Su kıtlı̆̆ı, insan ihtiyaçlarının karşılanmasında yeterli miktarda temiz suyun olmadığı durum olarak tanımlanmaktadır. Su kıtlığının analizinde evrensel bir standart tanım yoktur. Küresel su kıtlığını değerlendirmek için çeşitli ölçütler vardır. Falkenmark'ın (1989) su kıtlık endeksi, su kıtlığına neden olan faktörlerin ortaya çıkardığ 1 durumları kapsamaktadır. Su kıtlık endeksi, nüfusun bir fonsiyonu olarak su varlığının bir ölçütü, iklim ve kuraklık nedeniyle suyun eksikliğinin yarattığı gerçek su kıtlığı, kötü yönetim ya da aşırı nüfus nedeniyle suya erişmede azalma ile insan kaynaklı ve diğer faktörlerin sebep olduğu su kıtlı̆̆ arasındaki farkları anlamak için karşılaştırmalı olarak yapılmaktadır. Bu tanım, kıtlığın derecesi sınırlı su stresinden (> $1700 \mathrm{~m}^{3} / \mathrm{kişi} / \mathrm{y}$ ll), kesin su kıtlı̆̆ına $\left(<500 \mathrm{~m}^{3} / \mathrm{kişi} / \mathrm{y} 1\right)$ kadar uzanmaktadır (Padowski ve Jawitz, 2009, s.100).

Su yoksulluk endeksi ise, insani gelişim endeksi ile karşılaştırabilir bir yöntem kullanarak suyun sağlanmasında ülkelerin durumunu ölçen bir endekstir. Bunu yapmak için, beş ana bileşenden oluşan her bileşenin çeşitli alt bileşenleri ile ilgili bir endeks hazırlanmıştır (Lawrence, Meigh, ve Sullivan, 2002, s.4).

\section{SU YÖNETIMI VE KULLANIMI}

Dünya'da su kitlığı ve kıtlık dışında suya ilişkin birçok sorun su yönetiminden kaynaklanmaktadır. Türkiye'de 1960'lardan bu yana DSİ'nin yan dağıtım ağları için sulama birliklerine devretme programı vardı. Sulama birliklerinin değişen su taleplerine karşı en savunmasız ülke Türkiye'dir. Çünkü Türkiye bireysel birliklerin su hakkına sahip olmadığı bir ülke konumundadır. $\mathrm{Bu}$ sistem su konusunda az rekabetin olduğu yerlerde çalışmaktadır (Swendsen, Trava ve Johnson, 1997). BM verilerine göre, Türkiye kişi başına kullanılabilir su bakımından değerlendirmeye alınan 182 ülke arasından 103. sırada olduğu görülmektedir (TÜSİAD, 2008, s.5).

Gelişmekte olan ülkelerin çoğunda, sulama geliştirme projeleri ve bunların işletilmesi ve yönetilmesi, kamu sektörü tarafından yapılmaktadır. Önemli bir yönetim otoritesini başka bir kuruma devretmek beraberinde ulusal politika, yönetmelikler ve örgütsel yapıdaki değişiklikler, yerel düzeyde yeni kuruluşların oluşturulması, ekipman mülkiyeti devri ve personelde değişimler 
yapılmasını gerektirebilir. Su yönetiminin kamudan başka bir kuruma geçerek yönetimin el değiştirilmesi, problem çözmenin yanı sıra, daha önce kesin olarak ortaya çıkmamış yeni problemler yaratacaktır (Hamdy, 2004).

Türkiye'de su yönetiminde yeni anlayışa paralel olarak yapılanlar kapsamında önce yerel yönetimde belediyelerde yeni kurulan şirketlerle kara dayalı fiyatlandırma, sonra DSI'nin sulama işletmelerinin SB'ne devri gerçekleştirilmiştir. $\mathrm{Bu}$ durum su fiyatlarının artışına sebep olmuştur (Aydoğdu vd., 2015).

21. yüzyılda su kaynaklarının verimli ve etkin bir şekilde yönetilememesi, hizmetinin kalitesizliği ve bu bağlamda insan sağlığına etki eden negatif dişsalılıklar ortaya çıkmaktadır. Bütün bu olumsuzluklara çözümler getirilememesi, su hizmetlerinin kamu tarafından sağlanması sonucu oluşan faydanın maliyetlerden düşük çıkması, su için altyapı yatırımlarının zamanında yerine getirilememesi, düşük fiyatlar yüzünden suyun israfı gibi birçok sorunun suyun kötü yönetimi ve kullanımı yüzünden ortaya çıktığı varsayılmaktadır (TÜSİAD, 2008).

Tablo 3. Bölgesel Düzeyde Su Hizmetlerinin Yönetimi

\begin{tabular}{lcc}
\hline & \multicolumn{2}{c}{ Su Hizmetleri } \\
\cline { 2 - 3 } & Kamu & Özel \\
\hline Asya & 99 & 1 \\
Afrika & 97 & 3 \\
Orta ve Doğu Avrupa & 96 & 4 \\
Güney Amerika & 96 & 4 \\
Kuzey Amerika & 95 & 5 \\
Batı Avrupa & 80 & 20 \\
\hline
\end{tabular}

Kaynak: Güzelsarı ve Tuluay, (2011: 55)

Bölgeler itibariyle su kaynakları ve su hizmetlerinin yönetiminde özel sektörün payının kamunun payından düşük olduğu görülmektedir. Bu oranlar suda yapılacak olan özelleştirmeler için bir başlangıç sayılmaktadır. Yukarıdaki Tablo 5'de görüldüğü üzere su yönetimi bölgelerin gelişmişlik düzeylerine göre değişmektedir. Gelişmiş bölgelerde oranların payı nispeten 
yüksek iken, gelişmekte olan ve az gelişmiş bölgeler için bu oran düşüktür. Asya'da su hizmetlerinin verilmesinde özel sektörün payı \%1 iken, Batı Avrupa'da özel sektör payı \%20’ye çıkmaktadır

\section{SU ÖZELLEŞTİRME POLITIKASI VE İ̧̧LYIŞ BİÇIMI}

Dünya genelindeki ülkelerde yapılan özelleştirme uygulamalarında suya erişimin daha da zorlaştığı görülmektedir (Çınar, 2006, s.50).

DB, IMF, GATS ve DTÖ gibi uluslararası kuruluşlar az gelişmiş ve gelişmekte olan ülkelere suyun özelleştirilmesi konusunda gerekli ortamı hazırlayarak yol göstermektedirler. Su özelleştirilmesinde benimsedikleri politikanın genel yapısı şu şekildedir (Bulut, 2010, s.1):

$\checkmark$ Ülkelerdeki mevcut su altyapısı tamamen özel şirketlere devredilmeli,

$\checkmark$ Uzun süreli kiralamalar yapılmalı,

$\checkmark$ Uluslararası su şirketlerine belli bir ücret karşılığında görevler verilmelidir.

Özelleştirme, kamunun mülkiyeti ve yönetiminde olan kamusal mal ve hizmetlerin özel sektöre daimî veya geçici olarak devredilmesi işlemidir. Su özelleştirme sürecinde yaygın kullanım geçici olarak özel sektöre devridir. Hizmet özelleştirilmesinde, suyun tarımsal sulama ya da ev içi kullanımı, mülkiyet özelleştirmesinde ise endüstriyel kullanımı örnek gösterilebilir. Özelleştirmede yap-işlet-devret, imtiyaz sözleşmeleri, fiyatlama, kiralama, hizmet sözleşmesi, ortaklık, menkul kıymetleştirme gibi birçok yöntem uygulanmaktadır (TÜSİAD, 2008, s.126):

YID modelinin temel hedefi, kamu tarafindan gerçekleştirilmesi zor olan ve büyük finansman gerektiren bazı hizmetlerin, özel sektör tarafından yaptırılmasıdır. Bu model finansman avantajının dışında bazı dezavantajlara sebep olduğu için eleştirilmektedir. Yapılan uygulamalar sonucu bazı sektörlerde kaynak kullanımında israfa yol açması, yapım maliyetlerindeki yanlış fiyat belirlemeleri, fiyat belirlemede ve satın almada özel şirketlere ayrıcalık vermesi bu duruma örnek gösterilebilir.

İmtiyaz sözleşmeleri, özel firma bir hizmetin sunulmasında ekonomik riski yüklenerek hizmeti yerine getirmektedir. Özel firma masraflarının 
hizmetten yararlananlardan belirlenen ücret dahilinde finanse etmektedir (PPP, 2017). Belediye kullanıma sanayi suyu sağlamak, atık su yağmur suyunu uzaklaştırmak gibi hizmetleri imtiyaz sözleşmeleri ile yaparken, HES gibi farklı hizmetleri bu model atında yapmak mümkün değildir (TÜSİAD, 2008, s.130).

Özelleştirme yöntemlerinden olan kamu özel ortaklık yapılarında diğer bir yöntem menkul kıymetleştirme ve ortaklıktır. Kiralama yöntemi, özel firma bir hizmetin yerine getirilebilmesi için finansmanını sağlamaktadır. $\mathrm{Bu}$ yöntemde bu hizmeti önceden belirlenmiş ücret karşıllı̆ıında satın alma yoktur. Ancak proje bitirildikten sonra yapılan hizmet piyasa değeri karşılığında satın alınabilmektedir (PPP, 2017).

Kamu ve özel sektör arasında sermaye yatırımı ve varlık mülkiyeti gibi, hizmetlerin sorumluluklarının tahsisinin nasıl yapıldığına ilişkin modeller yer almaktadır. Daha fazla risk ve sorumluluk özel sektöre geçirilmekte ve hizmetleri iyileştirmek için daha güçlü teşvikler görülmektedir. Hizmet sözleşmelerinde ise, özel sektör üzerine çok az risk ve sorumluluk yüklenmektedir (Cowen, 1999, s.26).

$\mathrm{Bu}$ modellerin uygulanmasında farklı sonuçlar ortaya çıkmaktadır. Örneğin, kiralamada özel sektöre küçük ölçekli yatırımlar için çok az bir sorumluluk geçirilmekte ve yönetim sözleşmeleri, kiralama gibi modellerde bazı ticari risklerin özel sektöre geçirilmesinde geliri paylaşmak durumunda kalınabilmektedir. $\mathrm{Bu}$ yüzden kombinasyon yapılması gerekmektedir. Örneğin, su temininde yap-işlet-devret sözleşmesi dağıtım sisteminin işlemesi için, bir yönetim veya kiralama sözleşmesi ile birlikte yapılarak amaca ulaşılabilir (Cowen, 1999, s.26).

Su küresel önemde bir kaynak olduğundan IMF, DB, DTÖ gibi küresel ölçekli kurumlar su özelleştirmelerini teşvik etmişlerdir. Su özelleştirmelerinin gerçekleştirilmesinde öncü olan uluslararası kuruluşlardan az gelişmiş ülkeler su hizmetinin sağlanmasında, mali imkanların yetersizliği sebebiyle, bu kuruluşlardan kredi istemektedir. Küresel kuruluşlarda, bu krediler karşılığında suyun özel sektöre devrini sağlayan anlaşmalar yapmaktadır. Ancak özelleştirme amaçlı verilen kredilerin sadece \%20’lik 
kısmının sübvansiyon amaçlı olması hem suyun ticarileştiğini hem de suya erişemeyen yoksul kesimin aleyhine işlediğini göstermektedir.

\subsection{Krediler}

Uluslararası finans kuruluşları tarafından kamuya verilen krediler, ülkelerde yapılması planlanan su özelleştirmeleri için önemli bir finansman kaynağıdır. Çok uluslu su şirketleri için uluslararası finans kuruluşları özelleştirmelerde önemli bir rol üstlenmektedir. Bu kuruluşların planlanan özelleştirmeleri gerçekleştirmek için hazırladıkları koşullar şöyledir (Topçu, 2002, s.23):

$\checkmark$ IMF: Stand-by anlaşmaları ile kamu hizmetlerinin özelleştirilmesini istemektedir.

$\checkmark$ DB: Hükümetlere verdikleri kredilerin karşılığında özelleştirmeler yapılmasinı talep etmektedir.

$\checkmark$ Uluslararası Finans Kuruluşu (IFC): Sadece özel sektöre yatırım yapmaktadir.

$\checkmark$ Amerikalararası Kalkınma Bankası (IADB): Verdikleri kredilerde özelleştirmeyi 1srar etmektedir.

$\checkmark$ Çok Taraflı Yatırım Garanti Ajansı (MIGA): Su özelleştirmelerin yapılabilmesi için finansal garanti sağlamaktadır.

$\checkmark$ Avrupa Yatırım Bankası (EIB): Özelleştirmelerde Avrupalı özel şirketler için önemli bir kredi kaynağıdır.

$\checkmark$ Uluslararası Kalkınma Ajansı (IDA): Bu birim yükselen Afrika altyapı fonunu kurarak, Afrika'da özel alt yapı yatırımcılarına kredi vermeyi sağlamaktadır.

Verilen kredilerin karşılığında özelleştirme isteklerinin dışında, az gelişmiş ülkelerin sürdürülebilir kalkınmayı sağlamak için yabancı sermayeyi kendi ülkelerine çekebilmek amacıyla da bu yola başvurulmaktadır (Hall, 2002). 


\section{2. Özelleştirme Sorunları ve Yapısal Özelleştirmelerde Su Hizmetinin Başarısızlı̆̆ı}

$\mathrm{Su}$ hizmetinin verilmesi ve su kaynaklarının yönetiminde kamunun başarısızlığına karşı sunulan özelleştirilme sürecinde birçok sorun ortaya çıkmaktadır:

$\checkmark$ Tekelleşme: Su sektöründe özelleştirilen suyun \%70'ine sahip iki büyük Fransız su şirketi Suez ve Vivendi hâkimdir. Tekelleşme süreci ABD, Almanya, İspanya gibi ülkelerde şirket satın alma yolu ile devam etmektedir (Hall, 2002, s.5).

$\checkmark$ Fiyatlar: Suyun piyasalaştırılmasının bir gereği olarak fiyatlandırılma yapılmaktadır. Kamu finansman sağlamak için özel sektör ile özelleştirme sözleşmeleri yapmaktadır. Özel sektör de kar sağlamak ve maliyetleri kurtarmak amacı ile su tarifelerini yükseltmektedir. Artan su tarifelerine en iyi iki örnek Estonya ve Bulgaristan verilebilir. Bulgaristan'da yapılan sözleşme diş1 \%25,5 bir fiyat artışı yapılmıştır (Topçu, 2002, s.38).

$\checkmark$ Su Kalitesi ve Yatırım Eksikliği: Özelleştirme ile suyun kalitesi daha da kötüleşmiştir. Suyun özelleştirilmesi ile söz verilen altyapı yatırımları yapılmamıştır. Ortaya çıkan bu sorunlar için önemli bir örnek Arjantin'dir. Arjantin'de krizlerle birlikte dış borçların ödenememesi, su şirketlerinin karlarını olumsuz etkilemiştir. Arjantin'de özelleştirilen kamu hizmet kuruluşlarını işleten şirketler, çoğu zaman su tüketicileri ile karşı karşıya gelmiştir.

$\checkmark$ İşgücü: İşten çıkarmalar ve kesintiler özelleştirmenin en önemli iki yaptırımidir.

$\checkmark$ Hizmetten Dışlama ve Rekabet: Kamusal bir mal ve hizmetin özelliği olan tüketimden dışlamanın ve rekabetin olmadığı bu mallarda, suyun fiyatlandırılması ile bedelini ödeyemeyenler aleyhine bir durum oluşmaktadır.

Suyun özelleştirmelere konu olması, aynı zamanda suyun ekonomik açıdan yarattı̆̆ ticari boyutunun da ne kadar büyük olduğunu göstermektedir. Özellikle az gelişmiş ülkelerde bütçenin kısıtlı oluşu, iç ve dış borçlar gibi 
nedenlerle finansman sorunları yaşandığından, suya erişmede ve dağıtımında küresel su şirketlerinin yer aldığı özelleştirme yöntemleri devreye girmektedir.

\subsection{Türkiye'den Özelleştirme Örneği}

Türkiye'de su özelleştirmelerine dolaylı yollardan kamuoyuna bildirilmeden yapılmaya devam edilmektedir. Başlangıçta suda özelleştirmeler hidroelektrik santraller ile kendini göstermiş ve halkın tepkisiyle çatışmalar yaşanmıştır. HES'lerle başlatılan özelleştirme hareketleri süreci Türkiye'de birçok şehirde yapılmaya devam edilmektedir.

İzmir Çeşme'de, Çeşme-Alaçatı Su ve Kanalizasyon Projesi'nin finansmanında DB'den 13,1 milyon dolarlık kredi alınmış, karşılığında ise hizmet işletmeciliğinin devri için anlaşma yapılmıştır. $\mathrm{Bu}$ anlaşma, aynı zamanda Türkiye'ye de yükümlülük getirmiştir. Su temini ve atık su sisteminde özelleştirme ile beraber geç kalan yatırımlar, artan su fiyatları ve işletme maliyetleri gibi birçok olumsuzluklar ortaya çıkmıştır (TMMOB, 2009, s.62).

Antalya ilinin suyu, Fransız su devi Suez firmasının yönetimine geçmiş, su fiyatları özelleştirmeden sonra yüzde 13 artmıştır. Edirne suyunun özelleştirilmesinde yolsuzluk yaptığı ortaya çıkan konsorsiyumun, aynı yöntemlerle 9 kentte daha suyu özelleştirmeye çalıştığı ortaya çıkmıştır. İzmit Su Projesi 3996 sayılı kanun kapsamında gerçekleştirilen ilk Yap İşlet Devret (YID) projesidir.

Kütahya'da su özelleştirilmesi kapsamında içme suyu arıtma tesisleri, içme suyu hatları, derelerin 1slahı, su baskını yaşanan yerlerdeki rehabilitasyon bu kapsam dahilinde kabul edilmiştir. Su kaynaklarının korunması, geliştirilmesi, suların arıtılması ve niteliğinin arttırılması yapılan özelleştirmelerin temel hedefleridir. Kütahya Belediye Başkanı, yapılan özelleştirmeleri savunarak bu konuda halkın endişe duymasının yersiz olduğunu belirterek, bunun bir imtiyaz modeli olduğunu açıklamıştır (Ey, 2007). 
Günümüzde sudan ekonomik faydalanma amacı gün geçtikçe artmaktadır. Barajların son beş yılda dünyanın birçok ülkesinde hızı bir şekilde kurulmasının nedeni, artan sermayenin yatırım alanları aramasından kaynaklanmaktadır. Türkiye'de 2007 yılında GAP'ın bir parçası olarak Ilısu baraj projesi Ilısu konsorsiyumu ile Almanya, Avusturya, İsviçre hükümetine kredi teminatı yüzünden görüşmeler yapılmıştır. Baraj ve HES'ler yapıldıktan sonra altyapı yatırımları, yeniden yerleşim ve kamulaştırma maliyetin dışında gösterilmeye çalışılmıştır (Ayboğa, 2010, s.39).

\section{DEĞER PARADOKSU}

Elmas su paradoksu olarak da bilinen değer paradoksu, suyun ticarileştiğini göstermektedir. Adam Smith'in "Milletlerin Zenginliği” adlı kitabında toplam faydayı belirleyicilerin malın kullanım değeri ve değişim değeri olduğundan bahsetmektedir. Smith'e göre, bir malın ya da hizmetin kullanım değeri yüksek ise, değişim değeri de yüksek olması gerekir. Fakat uygulamada, suyun (toplumsal faydası) yani kullanım değeri çok yüksek olmasına karşılık değişim değeri azdır. Elmas içinse, durum tam tersidir. Elmasın kullanım değeri düşük, değişim değeri yüksektir. Aslında iktisadi açıdan olması gereken durum budur. Çünkü, elmasın değerini marjinal fayda belirlemektedir. Su toplam faydası yüksek, dolayısıyla kamusal bir maldır. Günümüzde su adına yaşanan süreçte suyun toplumsal faydası göz ardı edilerek, marjinal faydası yüksek ticari mala dönüştürülmeye çalışılmaktadır.

\section{FAYDA-MALIYYT ANALIZİ: TRABZON BÜYÜKŞEHİR BELEDIYYESI İÇME SUYU VE KANALIZASYON İDARESİ (TÍSKİ) ÖRNEĞİ}

\subsection{Faydanın Hesaplanması}

Suyun kullanılması, dağıtımı ve yönetiminde arz ve talep odaklı yöntemler kullanılmaktadır. Arz odaklı yöntemde, halkın kullanabileceği miktar fayda ve maliyet analizine dayanır. Su kaynaklarının korunması ve yönetimi, iklim değişiklikleri, enerji ve sanayi ile uyumlaştırılmış konular, bölgesel su birlikleri kurma gibi yöntemlerden oluşmaktadır. Talep odaklı 
yöntem suyu ticarileştiren bir yöntemdir. Suyun fiyatı talebe, yani piyasaya göre şekillenmektedir.

Hedef ve amaçların farklılaşmasıyla yatırımların değerlendirilmesinde ve analizinde de farklılıklar ortaya çıkmaktadır. Amaç kar etmekse, farklı metodlar kullanılmaktadır. Fakat amaç kar etmekten ziyade, bir hizmet sağlamak, toplumsal bir fayda yaratmaksa fayda-maliyet analizi kullanılır. Fayda, bir mal veya hizmetin insan ihtiyaçlarını karşılama özelliği olarak tanımlanmaktadır. Bu fayda kıtlıkla birlikte malın değerini belirlemektedir. Su toplumsal faydası çok yüksek kamusal bir mal olduğu için, faydası ölçülemez niteliktedir.

\section{2. İçme Suyu Maliyetinin Hesaplanması}

İçme suyu maliyetinin hesaplanmasında; içme suyu hesap giderinin, faturalandırılan yani satılan su miktarına bölünmesiyle elde edilmektedir.

Tablo 4. 2017 Yılında Şebekeye Verilen Su Miktarı

\begin{tabular}{ll}
\hline \multicolumn{1}{c}{ Su Miktarı } & $\mathbf{m}^{\mathbf{3}} / \mathbf{Y} \mathbf{l}$ \\
\hline Göze, Kuyu, Sondaj ve yüzeysel su kaynağından verilen su miktarı & 18.144 .632 \\
Arıtma tesisinden verilen su miktarı & 66.090 .310 \\
Şebekeye verilen Toplam su miktarı & 84.234 .942 \\
Faturalandırılan su miktarı & 28.734 .837 \\
\hline
\end{tabular}

Kaynak: TİSKİ (Faaliyet Raporu, 2017)

Tablo 6'ya göre Trabzon Büyükşehir Belediyesinin 2017 y1lında şebekeye verdiği su miktarları görülmektedir. Suyun maliyetinin hesaplanması için gerekli içme suyu giderleri hesapları elde edildikten sonra $1 \mathrm{~m}^{3}$ suyun maliyeti gösterilen formülle bulunmuş̧ur.

Tablo 5. İçme Suyu Giderleri²

\footnotetext{
${ }^{2}$ Suyun kaynak değeri hesaplamalara dâhil edilmemiştir.
} 


\section{7}

Mal ve hizmet alım giderleri $\quad 2.828 .627,16$

Sermaye Giderleri

$4.962 .796,64$

Toplam

$7.791 .423,80$

Kaynak: TİSKİ (Faaliyet Raporu, 2017)

$1 \mathrm{~m}^{3} \mathrm{Su}$ Maliyeti $=$ Y1llık Gider/Y1llık Satılan Su

Miktar1=7.791.423,80 / 28.734.837=0,271 TL

2017 y1lında üretilen su miktar1 $84.234 .942 \mathrm{~m}^{3}$, satılan su miktarı ise 28.734.837 $\mathrm{m}^{3}$ dür. Üretilen içme suyunun $1 \mathrm{~m}^{3}$ maliyeti ise $0,27 \mathrm{tl}$ 'dir. Toplam üretilen su miktarının \% 35'lik gibi çok az bir kısmı satılmıştır. \% 65'lik kısmı da şebeke kaybı ve ücretsiz verilen sulara denk gelmektedir. Bu aslında belediye için zarardır. Fakat buna rağmen Tiski'nin gelirleri giderlerini karşıladığ görülmektedir.

Tablo 6. TİSKİ 2017 Yı1ı Bütçe Gelirlerin Giderlerini Karşılama Oranı

\begin{tabular}{cccc}
\hline & $\begin{array}{c}\text { Toplam Gelir } \\
(\text { TL })\end{array}$ & $\begin{array}{c}\text { Toplam Gider } \\
(\text { TL })\end{array}$ & $\begin{array}{c}\text { Gelirin Gideri Karşılama } \\
\text { Oranı }\end{array}$ \\
\cline { 2 - 4 } 2017 & 168.442 .389 .97 & 167.547 .731 .67 & $\% 100.53-$ \\
\hline
\end{tabular}

Kaynak: TISSKİ (Faaliyet Raporu, 2017)

\section{TISSKI GENEL MÜDÜRLÜĞÜ SU TARIFESI}

Kanuni Dayanak: Tiski'nin 2560 sayıl1 yasasının 2'nci, 6'nc1, 9'uncu, 13'üncü ve 23 'üncü maddelerinde belirlenen görev alanı içerisinde çeşitli kaynaklardan sağladığı içme, kullanma ve sanayi sularının temini ve kullanıldıktan sonra uzaklaştırılmasıyla ilgili olarak abonelerine götürdüğü her türlü hizmetin bedeli, teminat ve yaptırımlarıyla, bunların tahsili esasları bu yönetmelikle düzenlenmektedir (TİSKİ, 2017).

Açıklama: İdarenin su satışı ücrete tabidir. Su ücretlerinin vadesinde ödenmemesi halinde yasal yollardan takip ve tahsil edilmektedir. Vatani hizmet tertibinden aylık bağlananlar, harp veya vazife malullüğü aylığı 
bağlananlar, dul ve yetim aylığı bağlananlar, Sosyal yardımlaşma vakfı kriterlerine göre ilgili belediyece muhtaç oldukları tespit edilenlere ve personele $\% 50$ indirim uygulamaktadır. Tarife cetvelinde tanımlanan her türlü ücret, vergi, harç vs. tutarlar KDV hariç hesaplanmıştır.

Madde 1: Su Tarifesi: $\mathrm{m}^{3} / \mathrm{Tl}$ bazında ücrete tabidir.

Madde 2: Tarife İndirim Oranları konutlarda, işyerlerinde ve inşaatlarda değişen indirim oranları uygulanmaktadır.

Madde 3: Mülga belde su tarifeleri beş y1l süreyle genel müdürlük tarifesinin $\% 50$ eksiği olarak belirtilmiştir.

Madde 4: Mülga köy su tarifeleri beş yıl süreyle genel müdürlük tarifesinin \% 75 eksiği olarak belirtilmiştir.

Madde 5: Usulsüzlük ve kaçak su tarifelelerinde beyanın farklılığına göre genel müdürlük tarifesinin \%50-300 fazlası olarak belirtilmiştir.

\subsection{Tarife Çeşitleri}

$\checkmark$ Sabit kademeli tarife yapısı: STS hizmetlerinin gerçek maliyeti hakkında görüş vermemekte ve makul ödenebilirlikte su hizmeti sunmaktadır. Su tasarrufunu teşvik etmemektedir (Muslu, 2015, s.23).

$\checkmark$ Artan kademeli tarife yapısı: Maliyetlerin geri dönüşümü ve ödeyebilirliği düşük su kullanıcılarına makul ödenebilirlikte su hizmeti sağlamaktadır. Çok su kullananları negatif teşvik ettiği için su tasarrufunu teşvik etmektedir. Kullanıcıların su hizmeti sisteminin geneline getirdikleri maliyet üzerinden ödeme yapmamas1, artan kademeli tarife yapısının diğer uygulamaları arasındadır.

$\checkmark$ Azalan kademeli tarife yapısı: Uygun düzenlendiğinde maliyetlerin geri dönüşü sağlanabilir. Az su yerine çok su kullanımını teşvik etmektedir. Sınırlı su kaynaklarına baskı artmaktadır. Düşük su kullananları negatif yönde teşvik etmektedir. Kullanıcıların su hizmeti sisteminin geneline getirdikleri maliyet üzerinden ödeme yapmaması azalan kademeli tarife yapısının özelliklerindendir. 


\section{TRABZON BÜYÜKŞEHİR BELEDIYYSINIIN SUYU FIYYATLANDIRMA POLITIKASI}

Trabzon büyükşsehir belediyesi, su hizmetleri kullanımında suyu fiyatlandırırken $\mathrm{m}^{3} / \mathrm{TL}$ bazında ücret kullanmaktadır. Toplumsal fayda gözetilerek kullanılan kademeli sistemler yoktur. Fiyatlandırma hem gelir elde etme hem de toplumsal fayda sağlama amaçlıdır. Bu konuda belirli bir hedefinin olduğu söylenilememektedir. Su kıtlığı endişesi ve dolayısıyla tüketimin kısılması yönünde tasarruf politikaları yoktur. Tiski'nin bütçe gelirlerinin giderleri karşılamada yeterli olduğu görülmektedir. Suyun kademeli tarife yerine ücrete dayalı olması, fiyatı belirlenirken talep odaklı yöntemlerin kullanılması suyun ticarileştiğinin en önemli göstergesidir.

\section{SONUÇ VE ÖNERILER}

Suyun sosyal ve ekonomik açıdan ne kadar önemli olduğunu fark eden küresel aktörler suya hâkim olmak için politikalar uygulamaya başlamıştır. Özellikle su kaynakları bakımından zengin olan Ortadoğu ve Orta Asya ülkelerine yönelik su stratejileri olması kaçınılmazdır. Bu durum karşısında küresel aktörlerin su stratejilerine karşı Ortadoğu Orta Asya ülkeleri arasında su birlikleri kurulabilir. Su birliklerinde su sıkıntısı çeken bölgelerdeki politikalar uluslararası hukuka uygun olarak yerel ve bölgesel iş birliği şeklinde gerçekleştirilebilir.

Su üzerinde şekillendirilen politikalar karşısında şu öneriler yapılabilir: Temiz suya erişim ve eşit miktarda erişimin bir insan hakkı olduğu, $\mathrm{Su}$ yaşamın sürdürülebilmesi için bir insan hakkıdır ve bu nedenle yaşam hakkından kimse mahrum edilemeyeceği, birlikte ve eşit tüketime konu olan bir kamu malı olduğu ve kamu mülkiyeti altında bulunması gerektiği, sosyal fayda ilkesi göz önünde bulundurulmalı, suyun bir insan hakkı olduğu, temiz suya eşit miktarda erişimin anayasa ile güvence altına alma, bir miktar suya kadar bedelsiz sunma, tüketimde rekabet olmaması ve dışlanamama, su hakkı, su kıtlığına özelleştirmeler yerine olumlu dışsallıklar yayan gerçekçi çözümler ortaya konulmalı, su yönetiminde talebe bağlı stratejiler yerine, arza bağlı 
stratejiler tercih edilmeli, küresel bir faktör olan küresel iklim değişikliklerinin su üzerindeki olumsuz etkilerine karşı talep odaklı yönetim teknikleri yerine arz odaklı yönetim teknikleri kullanılmalı.

Çalışmada suyun kamusallı̆̆g küresel Dünya'daki yaşanan gelişmeler ve uygulamalar 1şı̆̆ında Türkiye üzerindeki etkileri esas alınarak değerlendirilmiştir. Gerçekleştirilmiş özelleştirmelerin sosyal, toplumsal ve ekonomik açıdan ortaya çıkan dezavantajları, yaratacağı avantajları geçmiş olmasından dolayı suyun kamusal kalması gerektiği sonucuna varılmıştır.

\section{KAYNAKLAR}

Ayboğa, E. (2010). Yaşam hakkı olarak su. İstanbul: Onur Yayınevi.

Aydoğdu, M.H., \& Mancı, A.R., \&Aydoğdu, M. (2015). Tarımsal su yönetiminde değişimler; sulama birlikleri, fiyatlandırma ve özelleştirme süreci. Elektronik Sosyal Bilimler Dergisi, 14(52), 14. 10.17755/esosder.82927

Bulut, E. (2010). Suya göz koydular, Ölçü Dergisi, 1-11.

Cowen, P. B. (1999). The private sector in water and sanitation - how to get the started, The World Bank Group.

Çevre Mühendisleri Odası (2008). 2007 su raporu, Su ve Çevre, 18, 1-4.

Çınar, T. (2006). Su yönetimi ve finansmanında strateji model ve aktörler, T. Çınar ve H.K. Özdinç içinde, Su yönetimi küresel politika ve uygulamalara eleştiri, Ankara: Memleket Yayınları.

DPT (2007). Dokuzuncu kalkınma planı toprak ve su kaynaklarının kullanımı ve yönetimi, Özel İhtisas Komisyonu Raporu, Ankara: DPT Yayınları.

DSİ (2011). DSİ genel müdürlüğ̈̈ 2010 yll faaliyetrRaporu, Ankara: DSİ Yayınları.

Estache, A. ve Kouassi, E. (2002). Sector Organization, Governance, and the in Efficiency of African Water Utilities, http://rru.worldbank.org/Document/PapersLinks/1453.pdf adresinden alınd.

Ey, E. (2007). Kütahya'da içme suyunun özeleştirilmesi tartı̧malara yol açtı”, http://www.haberler.com/kutahya-da-icme-suyunun-ozellestirilmesihaberi/adresinden alındı. 
Güzelsarı, S ve Tuluay, N.F. (2011). Küresel su yönetimi ve suyun ticarileştirilmesi, Abant İzzet Baysal Üniversitesi Sosyal Bilimler Enstitüsü Dergisi, 1(22), 5280 .

Hamdy, A. (2004). Participatory Water Saving Management and Water Cultural Heritage. In : Hamdy A. (ed.), Tüzün M. (ed.), Lamaddalena N. (ed.), Todorovic M. (ed.), Bogliotti C. (ed.), s. 3-20. http://om.ciheam.org/om/pdf/b48/05002278.pdf, CIHEAM.adresinden alınd1.

Hall, D. (2002), Water multinationals 2002 financial and other problems, London: Public Services International Research Unit.

Hall, D. \& Lobina, E. (2005), The relative efficiency of public and private sector water, London: Public services international research unit.

Karakılçık, Y. (2011), Küresel aktörlerin su stratejileri ve bölgesel su birliği gerekliliği: avsubir, Akademik Yaklaşımlar Dergisi, 2(1), 74-90.

Kılıç, S. (2008). Küresel iklim değişikliği sürecinde su yönetimi, İstanbul Üniversitesi Siyasal Bilgiler Fakültesi Dergisi, 39, 161-186.

Lawrence, P., Meigh J., Sullivan C. (2002). The water poverty index: An international comparison, Keele Economics Research Papers, 19, 1-17.

Mert, A. (2008). Imf ve Dünya Bankası su politikaları, çok uluslu şirketlerin Türkiye'deki uygulamaları", TMMOB 2. Su Politikaları Kongresi Bildiriler Cilt-2, içinde 365-376.

Muslu, A.V. (2015). Dünya'da ve Türkiye'de suyun fiyatlandırılması (uzmanlık tezi), Ankara.

Öztunalı, G. (2002). Suya neden sahip çıkmalı? Mülkiye Dergisi, 26(234), 35-67.

Padowski, J.C. ve Jawitz J.W. (2000). The future of global water scarcity: policy and management challanges and opportunuties, The White head Journal of Diplomacy and International Relations, 99-114.

Public, Private Sector Cooperation (2017), PPP hakkında, http://www.ppp.org.tr/content/view/51/74/adresinden alınd1.

Shirley, M. ve Walsh, P. (2000). Public Versus Private Ownership: The Current State of the Debate, Washington DC: World Bank. 
Swendsen, M., Trava, J., Johnson, S.H., (1997). Participatory 1rrigation management: benefits, and second generation problems. International Irrigation Management Institue, https://www.researchgate.net/publication/266233089.adresinden alınd1.

TİSKİ (2017), faaliyet raporu 2017.

https://www.tiski.gov.tr/media/gallery/7f0b6b46-8df1-4595-ab21-

$\underline{84 c e 721 f 25 \mathrm{ad} . p d f}$ adresinden alınd1.

TİSKİ (2018), TISKI genel müdürlüğ̈̈ tarife cetveli, https://www.tiski.gov.tr/media/gallery/6882d4a5-59c2-4682-a04f889904846f07.pdfadresinden alınd1.

TMMOB (2009), Küresel su politikalarl ve Türkiye TMMOB su raporu, Ankara: Kardelen.

Topçu, F.H. (2002). Suda neler oluyor? Çok uluslu şirketler ve özelleştirmeler, Emek Araştırma Dergisi, 1(9), http://www.genelis.org.tr/upresimler/yayinlar/ gead/gead03-1.docadresinden alınd1.

TÜSİAD (2008), Türkiye'de su yönetimi sorunlar ve öneriler, İstanbul: TÜSİAD Yayınları.

USİAD (2007). Su raporu: ulusal su politikası ihtiyacımız, İstanbul: USİAD Yayınlar1.

Yıldız, D. (2004). Su kaynakları ve hidropolitik, Hidropolitik ve Stratejik Değerlendirme Uygulama ve Araştırma Merkezi http://topraksuenerji.org/kutuphane/Hidropolitik_ve_Su_Kaynaklari.pdf(07.0 5.2012)adresinden alınd1. 